\title{
Phytochemical Analysis, Antioxidant and Cytotoxic Potential of Rumex Vesicarius Extracts
}

\author{
Student Sabreen A. Alazzam ${ }^{1}$, Mohammed Mosleh Sharqi ${ }^{2}$, Ali F. AlMehemdi ${ }^{3}$ \\ ${ }^{1}$ Department of Biology, College of Science, ${ }^{2}$ Lecture, ${ }^{3}$ Prof., Center of Desert Studies, University of Anbar, Iraq
}

\begin{abstract}
Background: Rumex vesicarius L. (Polygonaceae), an edible plant, is documented to have many bioactive phytochemicals. In spite of it fully -known antioxidant efficacy of crude extract Rumex vesicarius but still has the cytotoxicity.

Methodology: Methanolic extraction was prepared from leaves of Rumex vesicarius and was checked by GC/MS. Two parts of assay were classified as : First, evaluation antioxidant potency using DPPH free radicals, while the two assay of MTT was utilized to determine anti-cancer effect on two different cell lines (MCF-7 and WRL68) for different concentrations $(400 \mu \mathrm{g} / \mathrm{ml}, 200 \mu \mathrm{g} / \mathrm{ml}, 100 \mu \mathrm{g} / \mathrm{ml}, 50 \mu \mathrm{g} / \mathrm{ml}$ and $25 \mu \mathrm{g} /$ $\mathrm{ml}$ and $6.2 \mu \mathrm{g} / \mathrm{mL}$ ) and identified the efficacy of the crude extract on MCF-7 cell morphology, response to stress, potential of mitochondria and viability were evaluated with High Content Scanning and MTT.

Results: GC/MS analysis showed the methanol extract of Rumex Vesicarius L. had the highest percentage of L- Pidolic Acid (35.98\%), vitamin E (12.05\%). R. Vesicarius showed antioxidant activity which increased when increasing of concentration, $R$. Vesicarius effect ranged from $(75.935,9.96 \%)$. The results showed Rumex vesicarius ability to inhibit cellular growth of both cell lines (WRL68 and MCF-7). This inhibition increases with increasing concentration. The best inhibition of growth was at $400 \mu \mathrm{g} / \mathrm{ml}$ of Methanol extract. The MCF-7 cell line was more effective than the WRL68 cell line, High Content Screening (HCS) assay of $200 \mu \mathrm{g} / \mathrm{ml}, 100 \mu \mathrm{g} / \mathrm{ml}, 50 \mu \mathrm{g} / \mathrm{ml}, 25 \mu \mathrm{g} / \mathrm{ml}$ and $12.5 \mu \mathrm{g} / \mathrm{ml}$ of methanol extract of R. Vesicarius showed toxic effects toward MCF-7 cell line after 24 hours of treatment in a dose-dependent manner with a reduction in the number of total cell count, reduction in the mitochondrial membrane potential (MMP), an increase in the nuclear intensity, increase in the membrane potential and increase in cytochrome $\mathrm{C}$.
\end{abstract}

Conclusion: Methanolic extract of Rumex vesicarius contains many bioactive phytochemicals and appear to have cytotoxic and antioxidant activity against MCF-7 \& WRL68 Cell line.

Keywords: Rumex vesicarius, Medicinal plants, Cytotoxicity, GC-MS analysis, High content screening.

\section{Introduction}

Rumex vesicarius is an annual plant, which belongs to family Polygonaceae, commonly known as "Bladder dock or Chukkakura or Khatta Palak"(1). Rumex vesicarius $\mathrm{L}$ is widely utilized as a medicinal herb or as food ${ }^{(2)}$. It is used in the treatment of liver defect, cancer, cardiovascular diseases and cataract (3), digestive problems, toothache, nausea, pain, antiinflammatory, antitumor as well as antischistosomal, and antimicrobial activities $^{(4)}$. It was also found to have an aphrodisiac effect ${ }^{(5)}$. Previous chemical investigations have shown the presence of polyphenols, flavonoids, carotenoids, tocopherols and ascorbic acid in different organs extract from Rumex vesicarius L. ${ }^{(6)}$, Polyphenols have essential roles such as functioning as antioxidant, anti-inflammatory, anticancer agents antimicrobial and antiallergic $^{(7)}$.

Phenolic compounds, tannins, anthocyanin, and flavonoids can play a role in free radical scavenging inhibition through different mechanisms ${ }^{(8)}$. Plant leaves 
are rich in ascorbic acid, citric acid and tartaric acid; it also contains glycoside, alkaloid, flavonoids, tannins and phenolic compounds ${ }^{(9)}$.

The aims of this study were to judge the antitumor and inhibitor activity of $\mathrm{R}$. vesicarius crude extracts in vitro used the human breast glandular cancer MCF-7and WRL68 cell line via has known of inhibitor activities against DPPH and evaluated the anti-tumour activity by using MTT assays and HCS for detective work the subsequent cellular parameters: membrane porousness, Cell viability, total nuclear intensity, cytochrome unleash and mitochondrial membrane potential changes.

\section{Materials and Method}

Materials: All artificial substances were luckily given from Al-Nahrain University, Department of Biotechnology. The MTT unit was nonheritable from desoxyribonucleic acid Biotechn, whereas 1Cellomics ${ }^{\circledR} 1$ Multiparameter of toxic three pack were obtained from ThermoScientifick (America).

Plant Materials: Leaves part of R. vesicarius were gathered from Ramadi University of Anbar, Iraq.

Methanolic Extraction: The leaves of $R$. vesicarius was dried and convert to powder form as $0.1 \mathrm{~g}$ then diluted with $400 \mathrm{~mL}$ alcohol methyl. Then homogenate the mixture using of a hot plate stirrer for four $\mathrm{h}$ at $37^{\circ} \mathrm{C}$ and then filtrated. The solvent was centrifugated with $1600 \mathrm{rpm}$ at $10^{\circ} \mathrm{C}$ for $20 \mathrm{~min}$. The alcoholiccrude material was dried at $46^{\circ} \mathrm{C}$ using a rotary evaporator) Germany) under vacuum to get the dried extract.

GC/MS Analysis: The extract of R. vesicarius was analysis by[ GC-2011 with equipped with DB5MS column (30 m long zero. $25 \mathrm{~mm}$ i.d. and $0.25 \mathrm{um}$ thick, Agilent Technologies, J and W Scientific product, America)]. The temperature of gizmo and detector were set at 240 and $235^{\circ} \mathrm{C}$, severally. The kitchen appliance temperature began with $100^{\circ} \mathrm{C}$ and raised till reach to $261^{\circ} \mathrm{C}$ for sixty sec. One $\mu \mathrm{L}$ of the sample as an aliquot of was injected, and gases noble gas was used.The mass varies scanned from[ (50-550) amu. Identification of matter and essential oils was done by the Ministry of Science and Technology, Department of Water and Environmental analysis (using government agency Library)].
Evaluation of antioxidant activity using DPPH: activity of inhibitor was calculable utilizing DPPH as radical commonplace looking on an antecedent study ${ }^{(10)}$.

Cell culture: Adenocarcinoma of breast tissue MCF-7 cells ${ }^{(11)}$. And Hepatic tissue WRL68 Cell Lines ${ }^{(12)}$ were purchased from USA Type Collection Cultured.

MTT cytotoxicity assay: The assay was done according to the instructions of the company, this test done according to ${ }^{(13)}$.

Multi-parameter cytotoxic assay: The doubleparameter toxicity experiment was done on live the 5 orthogonal MCF-7 cells normally health index once received to $\mathrm{R}$. vesicarius crude alcoholic extract in vitro. The parameters were: Viability cell count, total nuclear intensity, semi-permeable membrane porousiness, mitochondrial membrane porousness and cytochrome unharness. Briefly, once twenty-four $h$ of exposure with totally different concentrations of R. vesicarius alcoholic crude extract, the treated MCF-7 cells were stained with cell staining resolution for thirty $\min$ at $37^{\circ} \mathrm{C}$. Cells were mounted, permeabilized and blocked before inquiring with primary cytochrome protein and secondary DyLight [649 conjugated goat anti-mouselgG for sixty min] every. Plates were analyzed victimisation the ArrayScan HCS instrument.

Statistical data: A unidirectional analysis of variance (ANOVA) was done to evaluate whether or not cluster different was vital. Knowledge was represent as (Mean \pm standard error) (SE), and applied mathematics significances were allotted exploitation a Graph Pad Prism version.

\section{Results}

The analysis of GC/MS: methanol extract of $R$. vesicarius was showed in Table 1 and Fig 1, it appeared that the crud extract involves 24 active ingredients which represent $93.02 \%$. The are many active ingredient was Pidolic Acid 35.98\% followed by Phthalic acid, diisooctyl ester $12.09 \%$, Vitamin E ( $\alpha$-Tocopherol) 12.05, 9,12,15-Octadecatrienoic acid, (Z,Z,Z)- 10.41\%, 13-Tetradece-11-yn-1-ol 9.01\%, n-Hexadecanoic acid $5.54 \%, \gamma$-Tocopherol $4.75 \%$, Formic acid, 1-methylethyl ester $3.59 \%$, Hexadecanoic acid, 15-methyl-, methyl ester $2.87 \%, \alpha$-Tocopherol $2.67 \%, 2$-Methoxy-4vinylpheno $11.09 \%$. In addition, 10 parts were present in an amount less than 1\%.On the other aspect, 9.97\% still non-identified constituent. 
Table 1: Chemical contents of $R$. vesicarius alcoholic extract.

\begin{tabular}{|c|c|l|c|}
\hline Peak & Rt (min) & Compound & Area \% \\
\hline 1 & 2.41 & Formic acid, 1-methylethyl ester & 3.59 \\
\hline 2 & 11.45 & 2-Methoxy-4-vinylphenol & 1.09 \\
\hline 3 & 12.48 & Pidolic Acid - L & 35.98 \\
\hline 4 & 18.92 & Hexadecanoic acid, 15-methyl-, methyl ester & 2.87 \\
\hline 5 & 19.34 & n-Hexadecanoic acid & 5.54 \\
\hline 6 & 20.73 & $9,12,15$-Octadecatrienoic acid, (Z,Z,Z)- & 10.41 \\
\hline 7 & 21.15 & 13-Tetradece-11-yn-1-ol & 9.01 \\
\hline 8 & 24.70 & Phthalic acid, diisooctyl ester & 12.09 \\
\hline 9 & 28.12 & $\Delta$-Tocopherol & 2.67 \\
\hline 10 & 29.10 & $\gamma$-Tocopherol & 4.75 \\
\hline 11 & 30.30 & Vitamin E $(\alpha$-Tocopherol) & 12.05 \\
\hline
\end{tabular}

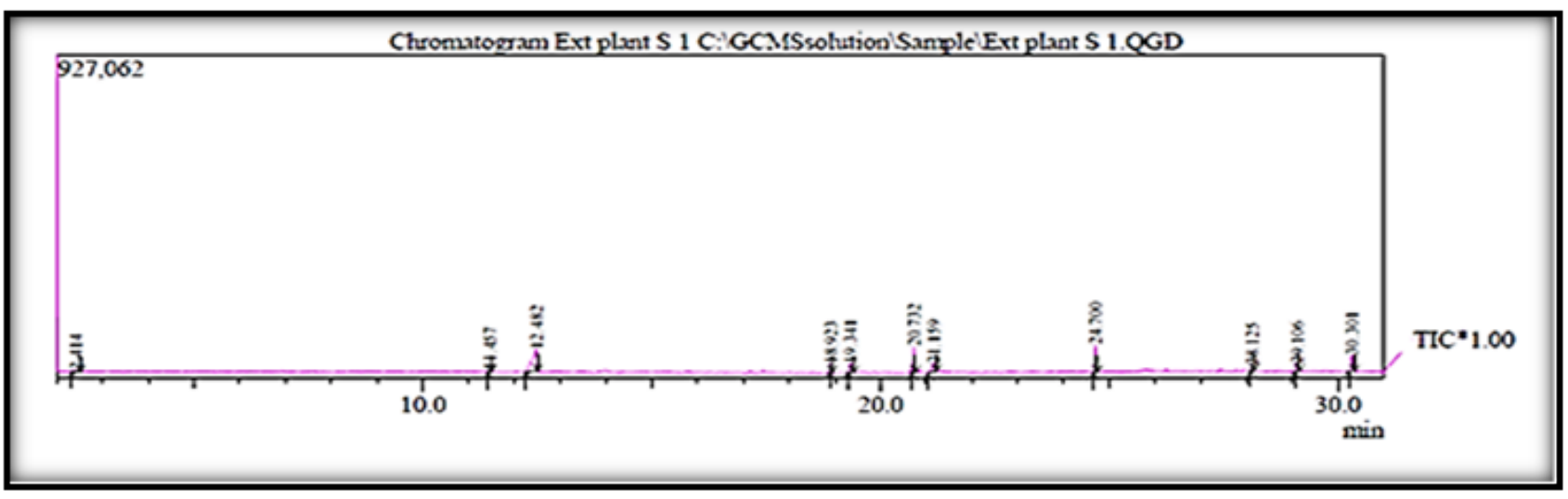

Fig. 1: GC-MS chromatogram of Rumex vesicarius L. of methanolic extract.

Antioxidant activity of Rumex vesicarius crude extract: The DPPH scavenging effect of $R$. vesicarius methanol was estimated. Data showed that with elevating dose of extract, the scavenger percent activity was increase. The doses of plant that were utilized from $12.5-100 \mu \mathrm{g} \mathrm{ml}^{-1}$ and the plant appear altitude antioxidant activity to give significantly value $(75.63 \%$ at $100 \mu \mathrm{g}$ $\mathrm{ml}^{-1}$ ). The data in Table 1, when compared with ascorbic acid standard drug the free radical scavenging activity, showed percent near from free radical scavenging activity, especially at high dose of extract with 50 and $100 \mu \mathrm{g} \mathrm{ml}^{-1}$.

Cytotoxic result of R. vesicarius extracts on MCF7cells and WRL68 Cell Lines mistreatment the MTT assay: Our result results showed that R. vesicarius extract has poisonous effect on carcinoma cells in dose dependent manner (Table 2).

Table 2: Anticancer activity of methanolic extract of R. vesicarius leaves on MCF-7 and WRL68 cell lines by using MTT method after $24 \mathrm{~h}$. of incubation at $37^{\circ} \mathrm{C}$.

\begin{tabular}{|c|c|c|c|c|c|c|c|c|c|}
\hline IC50 & $\mathbf{6 . 2}$ & $\mathbf{1 2 . 5}$ & $\mathbf{2 5}$ & $\mathbf{5 0}$ & $\mathbf{1 0 0}$ & $\mathbf{2 0 0}$ & $\mathbf{4 0 0}$ & \multicolumn{2}{|c|}{${\text { Concentration }\left(\boldsymbol{\mu g} / \mathbf{m l}^{\mathbf{1}}\right)}^{-1}$} \\
\hline 111.9 & $95.95 \pm 0.5$ & $95.72 \pm 1.2$ & $95.18 \pm 0.8$ & $78.74 \pm 7.0$ & $68.79 \pm 4.0$ & $46.10 \pm 4.6$ & $36.36 \pm 3.0$ & MCF7 & Methanol \\
\cline { 1 - 8 } extract
\end{tabular}

*MCF-7: human Breast cancer cell line, WRL68: human hepatic cell line. 
Multi-parameter cytotoxic activity of $\mathrm{R}$. vesicarius extract : Table (3) showed that $200 \mu \mathrm{g} / \mathrm{ml}$ of methanolic extract of $R$. vesicarius has cytotoxicity effect on MCF-7 cell line. $50 \mu \mathrm{g} / \mathrm{ml}, 25 \mu \mathrm{g} / \mathrm{ml}$ and 12.5 $\mu \mathrm{g} / \mathrm{ml}$ Showed results close to those of the untreated cells which represent the negative control with a very few significant differences.

From (Table 3 and Fig 2) methanolic extract significantly increased the nuclear intensity of the MCF7 cell line. This increasing was dose dependent $(37.8$ $\%, 8.2 \%, 7.3 \%, 2.8 \%$, and $6.8 \%$ for $200 \mu \mathrm{g} / \mathrm{ml}, 100 \mu \mathrm{g} /$ $\mathrm{ml}, 50 \mu \mathrm{g} / \mathrm{ml}, 25 \mu \mathrm{g} / \mathrm{ml}$ and $12.5 \mu \mathrm{g} / \mathrm{ml}$ respectively). The highest percentage of increasing was $37.8 \%$ at $200 \mu \mathrm{g} /$ $\mathrm{ml}$ when compared with untreated. $100 \mu \mathrm{g} / \mathrm{ml}, 50 \mu \mathrm{g} /$ $\mathrm{ml}, 25 \mu \mathrm{g} / \mathrm{ml}, 12.5 \mu \mathrm{g} / \mathrm{ml}$ did not show any significant differences from untreated.

Results of cytochrome $\mathrm{C}$ releasing listed in (Table 3) rise significantly with the increasing of concentration when compared with untreated and the percentages of increasing were $34.9 \%, 12.7 \%, 1.0 \%, 2.9 \%$ and $11.2 \%$ for $200 \mu \mathrm{g} / \mathrm{ml}$ and $100 \mu \mathrm{g} / \mathrm{ml}, 50 \mu \mathrm{g} / \mathrm{ml}, 25 \mu \mathrm{g} / \mathrm{ml}$ and $12.5 \mu \mathrm{g} / \mathrm{ml}$ respectively.

Table 3: Cytotoxicity effect of methanolic extract of $R$. vesicarius on multi cellular parameters after one day of overnight at $37^{\circ} \mathrm{C}$.

\begin{tabular}{|c|c|c|c|c|c|c|c|c|c|c|}
\hline \multirow{2}{*}{$\begin{array}{l}\text { Concentration } \\
\left(\mu \mathrm{g} / \mathrm{ml}^{-1}\right)\end{array}$} & \multicolumn{10}{|c|}{ HCS Parameters (Mean \pm SD) } \\
\hline & $\begin{array}{l}\text { Valid Cell } \\
\text { Count }\end{array}$ & $\mathbf{I H}^{*}$ & $\mathbf{N I}^{* *}$ & $\mathbf{I H}^{*}$ & MMP $^{* * *}$ & $\mathbf{I H}^{*}$ & $\mathbf{M P}^{* * * *}$ & $\mathbf{I H}^{*}$ & $\begin{array}{c}\text { Cytochrome } \\
\text { C }\end{array}$ & $\mathbf{I H}^{*}$ \\
\hline Dox 20 & $1411 \pm 90.6$ & 58.6 & $878.5 \pm 72.83$ & 101.7 & $245.0 \pm 26.87$ & 307.5 & $250.3 \pm 26.87$ & 87.3 & $732.0 \pm 166.3$ & 73.2 \\
\hline Untreated & $3411 \pm 163.4$ & 0.00 & $435.5 \pm 34.65$ & 0.00 & $552.5 \pm 96.87$ & 0.00 & $133.6 \pm 19.10$ & 0.00 & $422.5 \pm 87.8$ & 0.00 \\
\hline 200 & $2923 \pm 454.1$ & 14.3 & $600.5 \pm 14.85$ & 37.8 & $361.0 \pm 50.21$ & 34.6 & $156.5 \pm 4.96$ & 17.1 & $570.0 \pm 75.0$ & 34.9 \\
\hline 100 & $3238 \pm 226.4$ & 5.0 & $471.5 \pm 33.23$ & 8.2 & $426.5 \pm 45.70$ & 22.8 & $151.5 \pm 20.52$ & 13.3 & $476.5 \pm 173.6$ & 12.7 \\
\hline 50 & $3451 \pm 24.5$ & 1.1 & $467.5 \pm 38.89$ & 7.3 & $468.0 \pm 21.93$ & 18.0 & $141.1 \pm 9.91$ & 5.6 & $418.5 \pm 94.4$ & 1.0 \\
\hline 25 & $3441 \pm 186.8$ & 1.0 & $423.0 \pm 50.92$ & 2.8 & $505.0 \pm 21.93$ & 8.5 & $140.1 \pm 11.32$ & 4.8 & $410.0 \pm 37.9$ & 2.9 \\
\hline 12.5 & $3284 \pm 62.3$ & 3.8 & $405.5 \pm 24.75$ & 6.8 & $537.0 \pm 35.36$ & 2.8 & $132.6 \pm 19.10$ & 0.7 & $375.0 \pm 7.3$ & 11.2 \\
\hline
\end{tabular}

"In Hibition, ${ }^{* *}$ Nuclear Intensity, ${ }^{* * *}$ Mitochondrial Membrane Potential, ${ }^{* * * *}$ Membrane Potential

Nuclear Intensity Membrane Potentia

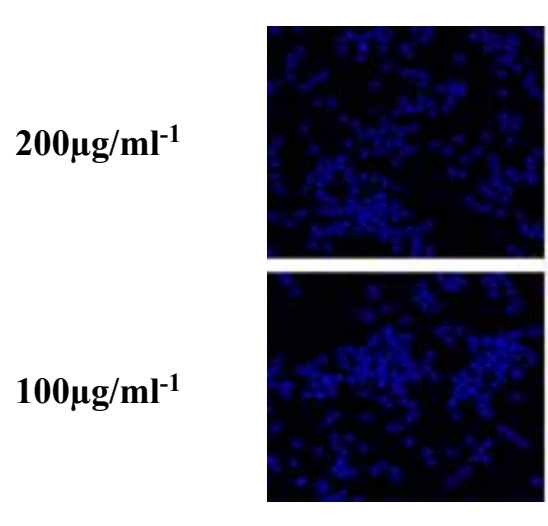

\section{Doxorubicin}

$20 \mu \mathrm{M}$
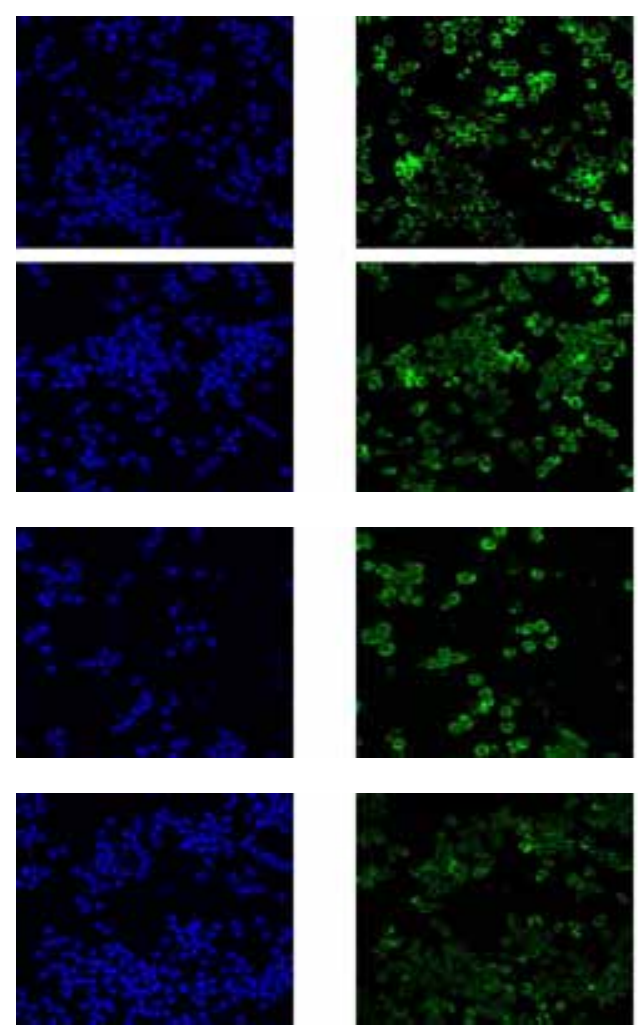

MMP
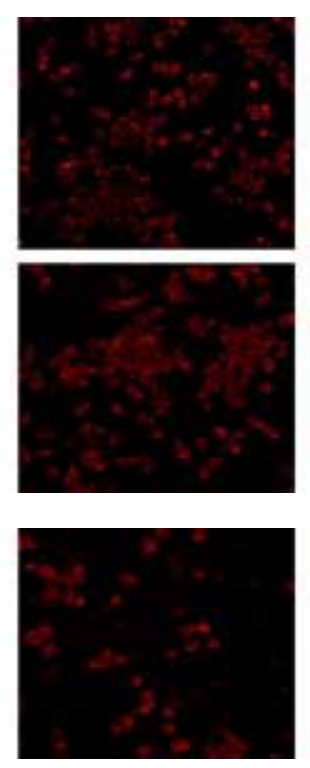

Cytochrome C
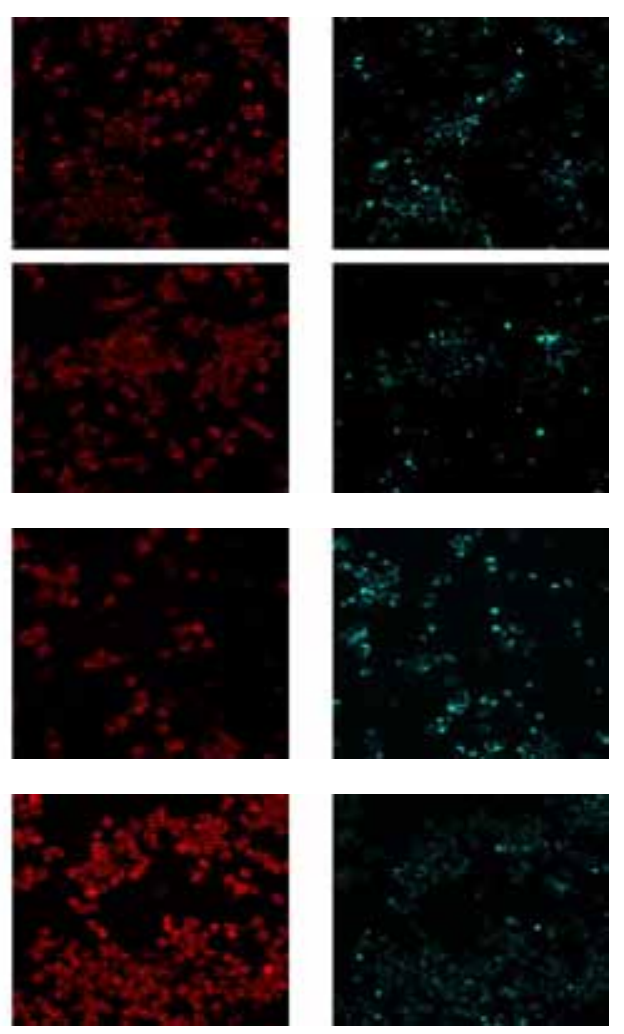
Vehicle Control: Fig.2: The analysis of $R$. vesicarius extract by $\mathrm{HCS}$ ) after treated the (MCF-7) cell line after one day of incubation at $37^{\circ} \mathrm{C}$. The stained cell by Hoechst 33342 (Blue)(Ex330nm/Em420nm) dye which capable of monitoring of cell loss, permeability dye nuclear morphology changes, (Green) (Ex491nm/ Em509nm) for monitor the membrane permeability, MMP dye (red)(Ex552nm/Em576nm) for changes potential mitochondrial membrane (PMM) and with second antibody conjugated with DyLight TM for cytochrome $\mathrm{C}$ releasing.

\section{Discussion}

In the current report, analysis by GC-MS of the $R$. vesicarius extract of a plant of leaves showed the presence of 11 compounds. Pidolic Acid, Phthalic acid, diisooctyl ester, Vitamin E ( $\alpha$-Tocopherol), 9,12,15-Octadecatrienoic acid, (Z,Z,Z)-, 13-Tetradece11-yn-1-ol, n-Hexadecanoic acid, $\gamma$-Tocopherol, Formic acid, 1-methylethyl ester, $\Delta$-Tocopherol and 2-Methoxy4-vinylphenol were consistent in the plant. These essential agent have all appear to have cancer inhibition, nematicide, pesticide, lubricant, antiandrogenic, insectifuge, 5-Alpha reductase inhibitor activity, antioxidant, hypochloesterolemic, haemolytic. There is a growing awareness in correlating the phytochemical compounds and their biological activities ${ }^{(14)}$.

Our study report the confirm of some of the essential agent identified by GC-MS analysis and their biological potency. Thus, this type of GC-MS analysis is the first line towards check the nature of active principles in this natural extract and this type of study will aid for further detailed in the future study.

Number of plants extract possess activity of antioxidant, which can limit the ROS in tissue and thus aid in a cure for different human problems, involves neoplasm, cardiovascular defect and inflammation (15). The $R$. vesicarius crude extract is often utilized as a medicinal herb due to biological activities, thus antioxidant activities ${ }^{(16)}$. However, little report about the effect of extract on antitumor activity. The harmful effect recorded with MCF-7 cells received to alcoholic crude extract maybe because of the contents of bioactive compounds, where they believe to be the major active ingredients of $R$. vesicarius that lead to a huge variety of biological effects. Such results are in concord with $^{(17)}$, which reported results showed that all extracts possessed concentration-dependent antioxidant activity.
In addition, this study concludes that Rumex vesicarius $L$ possesses diverse therapeutic potentials that might be used as natural antioxidant and antibacterial (16). Some studies demonstrate that all the extract of Rumex vesicarius. Shows the significant immunomodulatory effect on both humoral as well as cell-mediated immunity $(18 ; 19)$. On the other hand, the use of dye stained the membrane permeability and the elevated of intensity of this stains, especially at the massive dose received, potentiate the fact that the crude extract can stimulate apoptosis in MCF-7 cells, the permeability of plasma membrane increases may be because the loss integrity of membrane that dye penetrate cell easily ${ }^{(20 ; 21)}$.

The permeableness transition of mitochondrial pores, permitting the transition tiny molecules and ions, like atomic number 20 ions and therefore resulting in the decoupling of the metabolic process chain and unharness of cytochrome of the cytoplasm ${ }^{(22)}$. Finally, the secrete of a cytochrome stimulate a variety of caspases, specifically amino acid proteases, that ar essentially support digestion of the cell from within in addition as degradation $^{(23)}$.

Ethical Clearance: The Research Ethical Committee at scientific research by ethical approval of both environmental and health and higher education and scientific research ministries in Iraq

Conflict of Interest: The authors declare that they have no conflict of interest.

Funding: Self-funding

\section{References}

1. Subramaniyan, V.; Shaik, S.;Bag, A.;Manavalan, G. \& Chandiran, S. Potential action of Rumex vesicarius (L.) against potassium dichromate and gentamicin induced nephrotoxicity in experimental rats. Pakistan journal of pharmaceutical sciences, (2018). 31(2), 509-516.

2. El-Bakry, A.;Mostafa, H. \& Alam, E. Antioxidant activity of Rumex vesicarius L. at the vegetative stage of growth. Asian J Pharm Clin Res, (2012). 5(4), 111-117.

3. Laouini, S. E. \& Ouahrani, M.R. Phytochemical Screening, in Vitro Antioxidant and Antibacterial Activity of Rumex Vesicarius L. EXTRACT. Scientific Study \& Research. Chemistry \& Chemical Engineering, Biotechnology, Food Industry, (2017). 18(4), 367-376. 
4. El-Hawary, S.A.; Sokkar, N. M.; Ali, Z. Y. \& Yehia, M. M. A profile of bioactive compounds of Rumex vesicarius L. Journal of food science, (2011). 76(8), C1195-C1202.

5. Panduraju, T.; Rao, P. \& Kumar, V. A study on antimicrobial activity of Rumex vesicarius Linn. International Journal of Pharmacy and Technology, (2009). 1(1), 21-25.

6. Mostafa, H.; Elbakry, A. \& Eman, A. A. Evaluation of antibacterial and antioxidant activities of different plant parts of Rumex vesicarius L.(Polygonaceae). Int. J. Pharm. Pharm. Sci, (2011). 3(2), 109-18.

7. Kumar, N. \& Goel, N. Phenolic acids: Natural versatile molecules with promising therapeutic applications. Biotechnology Reports, (2019). e00370.

8. Suleman, M.;Khan, A.; Baqi, A.; Kakar, M. S. \& Ayub, M.. Antioxidants, its role in preventing free radicals and infectious diseases in human body. Pure and Applied Biology (PAB), (2019). 28(1), 380-388.

9. Mittler, R. ROS are good. Trends in plant science, (2017). 22(1), 11-19.

10. Sabry, F. A. Antitumor and Antioxidant Activity of Different Pelargonium graveolens Crude Leaves Extracts. Ministry of Higher Education. (2016).

11. A Al-Tamimi, M., Rastall, B., \& M Abu-Reidah, I. Chemical composition, cytotoxic, apoptotic and antioxidant activities of main commercial essential oils in Palestine: a comparative study. Medicines, (2016). 3(4), 27 .

12. Menshchikova, E.;Chechushkov, A.;Kozhin, P.;Kholshin, S.;Kandalintseva, N.;Martinovich, G. \& Zenkov, N. Activation of Autophagy and Nrf2 Signaling in Human Breast Adenocarcinoma MCF7 Cells by Novel Monophenolic Antioxidants. Cell and Tissue Biology, (2019). 13(2), 85-92.

13. Shing, C. Coriolus versicolor. Herbs and Natural Supplements, Volume 2: An Evidence-Based Guide, (2015). 2, 243.

14. Hariprasad, P. \& Ramakrishnan, N. (2011). GCMS analysis of Rumex vesicarius L. IJDDR 2011; 3 (2): 256, 263.
15. Krishnaiah, D.;Sarbatly, R. \& Nithyanandam, R. A review of the antioxidant potential of medicinal plant species. Food and bioproducts processing, (2011). 89(3), 217-233.

16. Manure, J. \& Naikwade, N. Immunomodulatory activity of leaves of RUMEX vesicarius LINN. and symplocos racemosa ROXB. International journal of pharmaceutical sciences and research, (2018). 9(4), 1537-1544.

17. Tukappa, A. \& Londonkar, R. L. Evaluation of antibacterial and antioxidant activities of different methanol extract of Rumex vesicarius L. Am. J. Drug Discov. Dev, (2013). 3, 72-83.

18. Abraham, V. C.;Towne, D. L.;Waring, J. F.;Warrior, U. \& Burns, D. J. Application of a high-content multiparameter cytotoxicity assay to prioritize compounds based on toxicity potential in humans. Journal of biomolecular screening, (2008). 13(6), 527-537.

19. Hamzah, K. J. \& Hasso, S. A. Molecular prevalence of Anaplasma phagocytophilum in sheep from Iraq. Open Veterinary Journal, (2019). 9(3), 238-245.

20. Ye, N.;Qin, J.;Shi, W.;Liu, X. \& Lin, B. Cellbased high content screening using an integrated microfluidic device. Lab on a Chip, (2007). 7(12), 1696-1704.

21. Jasim, A. M.;Hasan, H. F. \& Awady, M. J. Preparation of Vorapaxar loaded with Vitamin E TPGS and PVA emulsified PLGA nanoparticles In vitro studies. Research Journal of Pharmacy and Technology, (2019). 12(9), 4503-4510.

22. Susin, S. A.;Zamzami, N. \& Kroemer, G. Mitochondria as regulators of apoptosis: doubt no more. Biochimica et Biophysica Acta (BBA)Bioenergetics, (1998). 1366(1-2), 151-165.

23. Tafani, M.;Karpinich, N. O.;Hurster, K. A.;Pastorino, J. G.;Schneider, T.;Russo, M. A. \& Farber, J. L. Cytochrome c release upon Fas receptor activation depends on translocation of fulllength bid and the induction of the mitochondrial permeability transition. Journal of Biological Chemistry, (2002). 277(12), 10073-10082. 